\title{
Gender dan Pendidikan Tinggi: Studi tentang Urgensitas Kampus Berperspektif Gender
}

\author{
Ika Arinia Indriyany ${ }^{1}$, M. Dian Hikmawan ${ }^{2}$, Wahyu Kartiko Utami ${ }^{3}$ \\ 1,2,3 Program Studi Ilmu Pemerintahan, Universitas Sultan Ageng Tirtayasa
}

Dikirimkan: 12 November 2020 Direvisi: 3 Februari $2021 \quad$ Diterbitkan: 25 Maret 2021

\begin{abstract}
INTISARI
Ketimpangan gender merupakan sebuah masalah dalam kehidupan sosial masyarakat diseluruh dunia. Perempuan selalu di posisikan pada suatu kondisi sub-ordinasi karena identitas dan historisitas peradaban manusia yang selalu menempatkan perempuan menjadi yang kedua. Dengan hadirnya bentuk negara dan relasi antar warga negara yang dijamin oleh negara tanpa terkecuali, memungkinkan perempuan agar dapat menempati ruang publik ini secara setara. Riset ini mengulas dinamika dan artikulasi kesetaraan gender diranah perguruan tinggi, dengan pendekatan fenomenologis, riset ini berupaya memaknai dan melihat aktualisasi kebijakan kampus dalam mendorong persfektif gender menjadi agenda dalam mengembangkan kampus yang bersfektif gender. Hasil dari riset ini menunjukan bagaimana dinamika perempuan dalam mencapai kesetaraan gender pada ruang lingkup perguruan tinggi.
\end{abstract}

KATA KUNCl

gender; perguruan tinggi; ketimpangan; kesetaraan

\section{Pendahuluan}

Fokus bahasan dalam tulisan ini akan mengkaji lebih lanjut urgensi dari keberadaan kampus berperspektif gender ditengah maraknya kasus terkait relasi gender yang timpang di perguruan tinggi. Disorotnya respon kampus yang beragam dalam merespon permasalahan terkait gender, seperti pelecehan seksual antara mahasiswa maupun dosen dengan mahasiswa membuat wacana kampus berperspektif gender menjadi penting untuk ditelisik. Gender atau jenis kelamin sosial adalah adalah sebuah cara pandang dalam melihat dan memahami sifat - sifat laki - laki dan perempuan yang sifatnya berasal dari konstruksi sosial (Fakih, 1996). Gender atau bisa disebut juga sebagai jenis kelamin sosial merupakan suatu perspektif yang membedakan laki-laki dengan perempuan, namun hal ini berbeda dengan jenis kelamin secara biologis, namun lebih ke konstruksi sosial antara keduanya. Dalam hal ini, gender sangat bergantung pada kontruksi sosial, nilai, norma, maupun setting sosial budaya yang ada masyarakat, sehingga sifatnya pun menjadi lebih cair dan mudah untuk dipertukarkan. Gender sering

Korespodensi:

Prodi Ilmu Pemerintahan, Fakultas Ilmu Sosial dan Ilmu Politik, Universitas Sultan Ageng Tirtayasa, J Raya Jakarta KM 04 Pakupatan Serang-Banten.

Email: dian.hikmawan@untirta.ac.id 
juga dikaitkan dengan ketimpangan gender. Ketimpangan gender terjadi saat relasi kekuasaan yang ada pada laki - laki dan perempuan tidak setara. Laki - laki diposisikan superior dan perempuan diposisikan subordinat dari laki - laki, hanya karena jenis kelaminnya yang perempuan. Subordinasinya posisi perempuan pada laki - laki berdampak banyak hal seperti ketimpangan di bidang ekonomi, pendidikan, kesehatan hingga stabilitas politik (Cerise \& Francavilla, 2012).

Asumsi dasar untuk melacak ketimpangan gender adalah dengan melihat relasi kekuasan antara laki - laki dan perempuan (Hannam, 2012). Laki - laki diasumsikan memiliki kekuasaan yang lebih tinggi sehingga diposisikan lebih superior dibandingkan perempuan. Pandangan ini menegasikan posisi perempuan yang seharusnya juga memiliki kuasa dan otonomi penuh, minimal atas tubuh mereka sendiri. Relasi ini kemudian dilanggengkan dalam masyarakat dengan nilai budaya patriarki yang kuat. partriarki merupakan sebuah sistem dimana laki - laki mendominasi dan menguasai aspek kehidupan sehingga bentuk penomorduaan pada perempuan dianggap sebagai hal yang wajar oleh masyarakat (Farmawati, 2018).

Permasalahan terkait gender ada dalam setiap aspek kehidupan bermasyarakat, salah satunya adalah di dunia pendidikan tinggi. Menurut data yang dipublikasikan oleh Kementerian Pendidikan dan Kebudayaan, saat ini terdapat 4597 Perguruan Tinggi swasta dan negeri yang tersebar di seluruh Indonesia, baik itu yang berbentuk universitas, institut, sekolah tinggi, akademi, akademi komunitas maupun politeknik (Dikti, 2018). Perguruan Tinggi ini menaungi 8.400.877 orang mahasiswa dan 286.116 orang dosen. Mahasiswa terbagi menjadi mahasiswa laki - laki sebanyak 3.099.783 dan mahasiswa perempuan sebanyak 3.250 .158

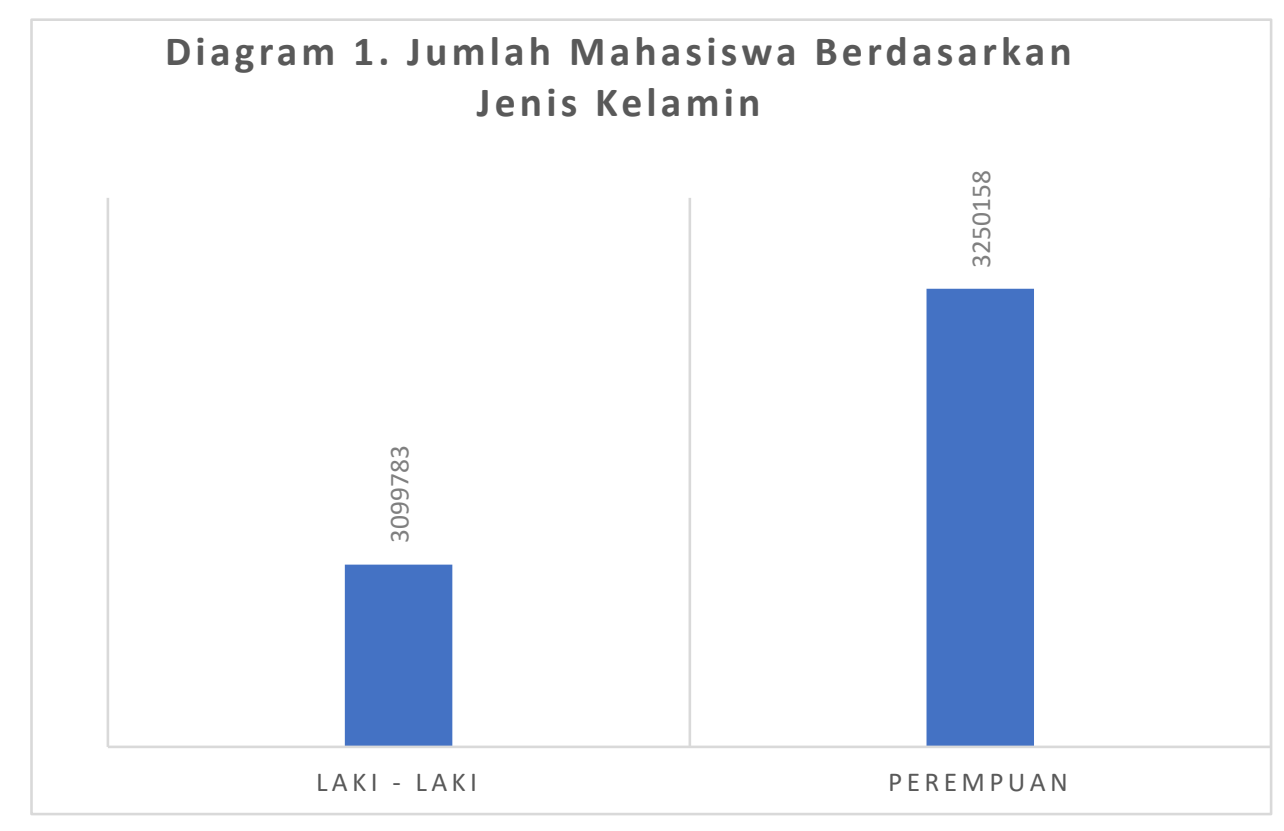

Sumber: (Dikti, 2018) 
Sedangkan untuk dosen, 286.116 orang ini terbagi menjadi 166.979 dosen berjenis kelamin laki - laki dan 129.021 dosen perempuan. Visualisasi sebaran dosen berdasarkan jenis kelamin dapat dilihat melalui diagram berikut ini.

\section{Diagram 2. Jumlah Dosen Berdasarkan Jenis Kelamin}

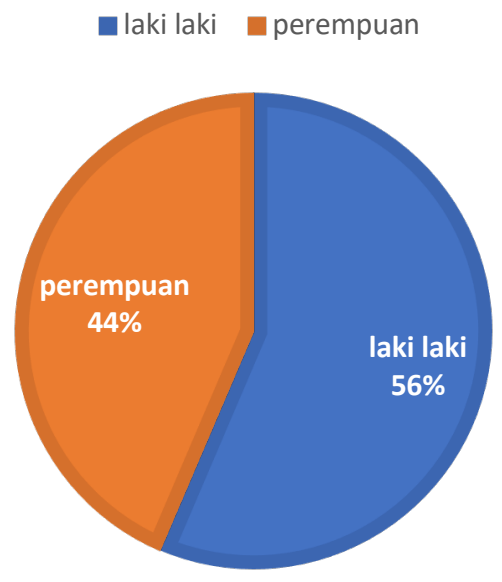

Sumber: (Dikti, 2018)

Keberadaan perempuan baik mahasiswa maupun dosen dengan jumlah yang tidak sedikit ini menuntut perhatian pemangku kepentingan di kampus agar kebutuhan mereka terakomodasi dan tidak terjadi ketimpangan jumlah tenaga kerja berdasarkan jenis kelamin. Ketimpangan jumlah tenaga kerja berdasarkan jenis kelamin ini dapat menjadi salah satu penyebab ketimpangan gender, baik di lingkungan pemerintahan hingga swasta. Begitu juga dilingkungan kampus yang mana masih banyak terjadi ketimpangan gender.

Pertama, belum meratanya sebaran dosen perempuan pada program studi yang ditawarkan kampus - kampus di Indonesia. Program Studi yang lekat stereotipnya dengan karakteristik perempuan seperti kesehatan, pendidikan dan ekonomi di dominasi oleh dosen perempuan (Aruan, 2019). Sebaliknya, prodi yang lekat stereotipnya dengan maskulinitas laki-laki seperti prodi STEM (Science, Technology, Engineering, Mathematics) jumlah keterlibatan perempuan sangat minim jika dibandingkan dengan laki - laki (Jurnal Perempuan, 2016).

Dalam publikasinya Jurnal Perempuan menyebutkan bahwa minimnya peran perempuan dalam STEM disebabkan karena perempuan sejak kecil mengalami diskoneksi atas akses teknologi akibat dari tidak adanya dukungan budaya dan lingkungan pada anak maupun perempuan untuk menguasai bidang ini. Padahal riset yang dilakukan oleh World Bank menunjukkan bahwa ada korelasi antara penguasaan bidang STEM dengan pembangunan nasional. 


\section{Diagram 3 Korelasi Penguasaan Bidang STEM dengan Pembangunan Nasional}

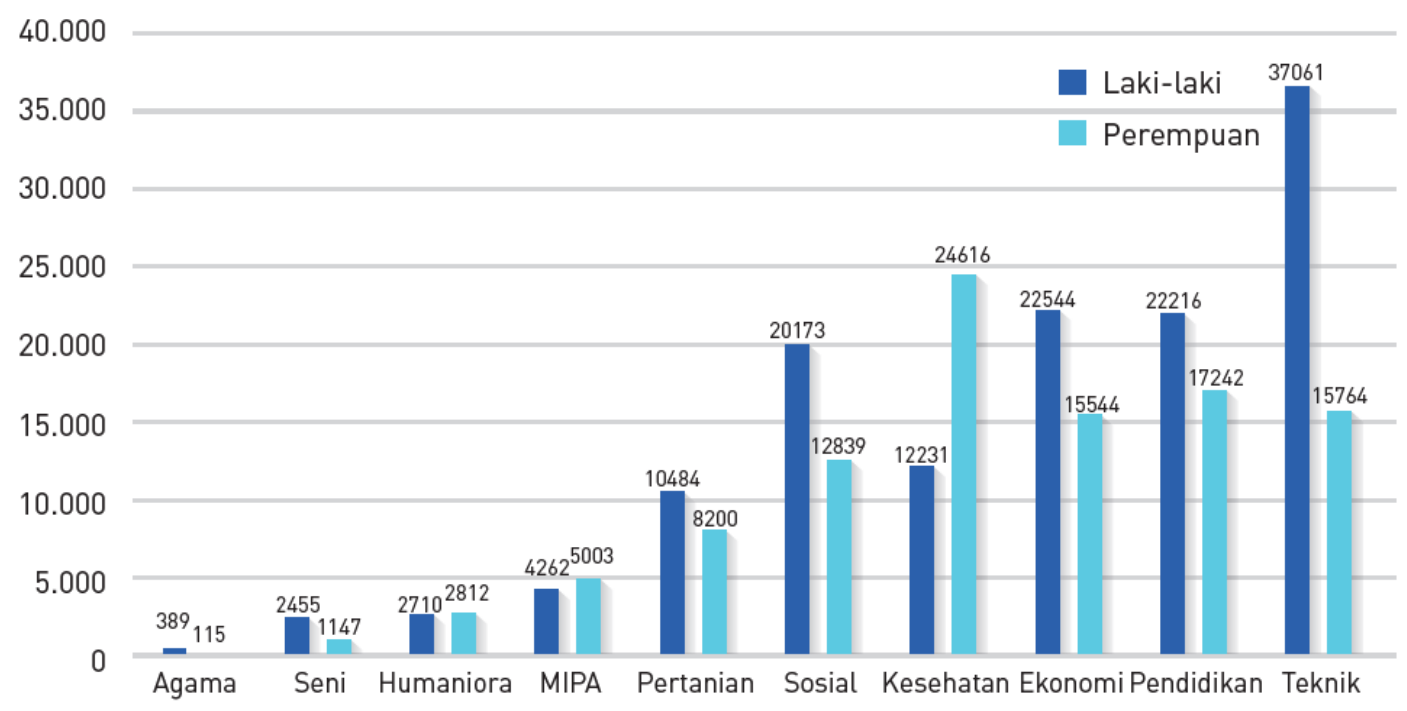

Sumber : (Aruan, 2019)

Di kampus Universitas Sultan Ageng Tirtayasa Banten (Untirta) ketidakmerataan perempuan dan laki - laki terlihat dari keterwakilan perempuan pada jabatan Pimpinan Universitas. Dari 22 jabatan pimpinan seperti Rektor, Wakil Rektor, Dekan dan Kepala Lembaga hanya ada 1 pimpinan perempuan sebagai Dekan (4\%). Di Kementerian Pendidikan dan Kebudayaan sendiri yang menaungi pendidikan tinggi, jabatan struktural eselon 1 dan 2 juga didominasi oleh laki - laki. Dari 64 posisi yang tersedia, jabatan yang dipegang oleh perempuan hanya 15 posisi atau $23 \%$.

Minimnya representasi perempuan pada jabatan struktural pimpinan perguruan tinggi ini menyiratkan pertanyaan. Apakah memang perempuan tidak memiliki kapasitas untuk menjadi pemimpin? atau persoalannya bukan mengenai kapasitas tetapi mengenai akses yang tertutup akibat konstruksi sosial maupun setting lingkungan sosial budaya yang tidak memberikan kesempatan bagi perempuan untuk menduduki jabatan pimpinan. Konstruksi sosial terhadap perempuan terkait dengan kodrat yang selama ini dilekati pada perempuan bahwa perempuan dianggap hanya bisa menyelesaikan urusan domestik (Alfirahmi, 2018).

Kepemimpinan pada sebuah jabatan struktural dianggap bukanlah ranah domestik, tetapi ranah publik diluar kapasitas dan kewenangan perempuan. Berdasarkan konstruksi agama, kepemimpinan dikaitkan dengan kapasitas laki - laki sebagai imam. Sedangkan konstruksi budaya patriarki mengasumsikan perempuan tidak akan mempu memimpin karena juga dibebani oleh urusan domestik (double burden), sedangkan kepemimpinan berada dalam ranah publik. Dampak dari minimnya keterwakilan perempuan di ranah pendidikan tinggi (baik kementerian maupun kampus) 
berimbas pada kurang terakomodasinya kebutuhan perempuan. Hal ini berhubungan dengan masalah ketimpangan gender.

Kedua, yaitu minimnya infrastuktur responsif gender di kampus. Infrastruktur responsif gender adalah infrastruktur yang memperhatikan perbedaan kebutuhan, hambatan/kesulitan, aspirasi kelompok laki - laki dan perempuan termasuk juga kelompok lanjut usia, penyandang disabilitas, anak dan kelompok rentan yang lainnya (Indrarini, 2020). Infrastruktur responsif gender mengindikasikan sarana prasarana yang inklusif dan mampu mengakomodasi kebutuhan semua pihak. Untuk mewujudkan sarana prasarana yang responsif gender maka dibutuhkan analisa yang mendalam terkait dengan kebutuhan laki - laki, perempuan maupun penyandang disabilitas. Minimnya infratruktur responsif gender salah satunya disebabkan karena kebijakan pengarusutamaan gender di perguruan tinggi yang masih minim. Pendidikan yang dijalankan di perguruan tinggi masih diselenggarakan secara netral gender dengan tidak fokus pada pengakomodasian perbedaan kebutuhan peserta didik.

Beberapa masalah terkait penyediaan infrastruktur yang tidak responsif gender diantaranya adalah keberadaan toilet yang sama antara toilet laki - laki, perempuan dan penyandang disabilitas. Padahal jika dianalisa lebih lanjut, ketiga kelompok ini memiliki kebutuhan yang berbeda terkait toilet. Perempuan membutuhkan toilet dengan kelengkapan yang lebih detail seperti gantungan untuk menggantungkan tas, tempat sampah untuk membuang pembalut habis pakai, cermin, tisu, dan kebutuhan lainnya. Sedangkan penyandang disabilitas kebutuhannya jauh lebih rumit seperti pintu yang lebih lebar agar kursi roda bisa masuk ke dalam toilet, pegangan tangan untuk disabilitas netra, pintu dengan desain pintu geser agar disabilitas daksa tidak kesulitan membuka dan menutup pintu, hingga keberadaan kloset yang aksesibel. Infrastruktur lain yang juga harus menjadi perhatian adalah keberadaan tangga. Tangga perlu diperhatikan agar tidak terlalu curam dan tidak terlalu tinggi anak tangganya agar tidak menyulitkan perempuan yang sudah berusia lanjut ataupun perempuan yang menggunakan rok. Tetapi keberadaan tangga saja akan menyulitkan mobilitas penyandang disabilitas.

Kampus dengan desain gedung lama biasanya hanya memiliki tangga saja sehingga disabilitas daksa pengguna tongkat kruk atau kaki palsu akan kesulitan. Dibutuhkan ramp atau bidang miring yang landai agar memudahkan pengguna kursi roda. Infrastruktur berikutnya yang juga sering diabaikan di kampus adalah ketersediaan ruang laktasi bagi ibu menyusui. Ruang laktasi penting bagi ibu pekerja agar tetap bisa menjalankan perannya menyusui dengan privasi yang terjaga tetapi pada saat yang bersamaan juga dapat menjalannya perannya dengan baik di ruang publik (bekerja).

Sayangnya kebutuhan - kebutuhan penting ini tidak akan ditangkap oleh pemimpin mereka bekerja. Kurangnya pemahaman akan urgensitas kesetaraan gender pada pemimpin mereka ini, pada akhirnya mengasumsikan bahwa kebutuhan perempuan dan penyandang disabilitas bisa digeneralisir dengan kebutuhan laki - laki. Pemimpin yang tidak sadar dan tidak berperspektif gender akan menganggap bahwa 
mengakomodasi kebutuhan infrastruktur menambah beban bagi instansi. Oleh karena itu dibutuhkan keterwakilan perempuan yang mampu memahami keberbedaan kebutuhan yang dipunyai oleh perempuan dan penyandang disabilitas.

Ketiga, ketimpangan gender di kampus tercermin melalui masih terjadinya pelecehan seksual baik yang dilakukan sesama mahasiswa maupun dosen terhadap mahasiswa. Beberapa kampus besar pernah menjadi sorotan atas terjadinya pelecehan seksual di kampusnya. UGM pernah menjadi viral di tahun 2016 saat salah satu media daring memberitakan tentang kasus pelecehan yang dilakukan dosen terhadap mahasiswa berkedok bimbingan paper (Button, 2016). Korban diminta untuk menemui dosen tsb karena mengumpulkan tugas terlambat. Mahasiswa yang tidak punya pilihan akhirnya menyetujui untuk bertemu di pusat kajian tempat dosen tersebut aktif melakukan penelitian.

Di sanalah pelecehan tersebut terjadi. Meskipun akhirnya, fakultas menjatuhkan sanksi akademik berupa pelepasan tanggungjawab Tri Darma Perguruan Tinggi pada dosen tersebut dan mengirimkan dosen tersebut untuk melakukan konseling ke salah satu women crisis center, tetapi menurut korban pelaku masih bebas berkeliaran di kampus. Pada tahun 2018, UGM kembali menjadi disorot atas lemahnya respon pada kasus perkosaan yang terjadi di mahasiswanya pada saat KKN. UGM dinilai tidak melakukan upaya - upaya yang pro terhadap korban karena justru memberikan punishment pada penyintas (Nilai C), bukannya menghukum pelaku perkosaan (Maudy, 2018). Pada perkembangannya kasus ini menghadirkan berbagai aksi untuk mengkawal penyelesaian kasus seperti aksi 'UGM Darurat Kekerasan Seksual', 'Agni adalah Kita', 'Kita Agni', dll.

Kampus besar lain yang juga disorot dalam penangannya terhadap kasus pelecehan seksual adalah Universitas Airlangga. Unair menjadi viral di dunia maya saat unggahan terkait Predator Fetish Kain Jarik dibaca dan dikomentari oleh banyak pengguna sosial media. Mahasiswa Unair diduga melakukan pelecehan seksual karena memaksa korbannya untuk mengikat dan membungkus dirinya dengan menggunakan kain jarik dengan modus penelitian akademis. Korban yang kebanyakan adalah laki - laki merasa tidak curiga karena memang berniat membantu riset senior. Unair mendapatkan respon positif saat mereka dengan berani menyatakan sikap untuk mendrop out pelaku yang juga mahasiswa kampus tersebut setelah serangkaian proses investigasi (Faizal, 2020). Selain itu Unair juga menyediakan layanan konseling bagi korban dengan penjaminan atas kerahasiaan identitas korban (Kurniawan, 2020).

Adanya ketidaksetaraan gender yang terjadi diberbagai kehidupan masyarakat inilah yang kemudian membuat banyak peneliti tertarik untuk melihat isu ini lebih jauh. Riset pertama adalah “Dinamika Pengarusutaman Gender pada Pendidikan Tinggi Islam" (Kusmanto, 2017). Riset ini berusaha melihat bagaimana konsep pengarustamaan gender diterapkan di UIN Walisongo. Implementasi konsep ini masih belum seutuhnya dijalankan karena pimpinan UIN Walisongo masih memahami pengarustamaan gender 
sebagai konsep yang berasal dari luar institusi sehingga pemahamannya menjadi parsial dan terbatas. Meskipun begitu, UIN Walisongo tetap berusaha menjalankan konsep ini dengan berbagai kebijakan di bidang Tri Darma Perguruan Tinggi maupun sisi pengelolaan SDM dimana ada kesempatan yang sama bagi perempuan untuk menempati posisi jabatan struktural.

Riset kedua adalah "Pendidikan Berbasis Kesetaraan Gender di Provinsi Jawa Tengah" (Roziqin, Suwitri, Apryanto, \& Sihidi, 2019). Penelitian ini mengungkapkan bahwa penting untuk memastikan bahwa pendidikan harus didasarkan pada kesetaraan gender, yang tercermin melalui pengembangan kurikulum, tenaga pendidik yang pro pada kesetaraan gender dan bahan ajar yang peka pada isu gender. Sehingga perempuan tidak lagi hanya dikotakkan ke dalam urusan domestik (Ibu Rumah Tangga) tetapi juga memiliki kesempatan yang sama di ranah publik Bersama dengan laki - laki. Oleh karena itu maka akses pendidikan tanpa terkecuali tidak boleh dibedakan berdasarkan jenis kelamin.

Riset ketiga adalah "Analisis Kebijakan Pendidikan Berwawasan Gender" (Jabar, Djamas, \& Latisma, 2012). Penelitian ini memberikan saran terhadap Universitas Negeri Padang agar pendidikan yang dijalankan dapat berwawasan gender, seperti menyusun profil gender untuk pemerataan akses dan kualitas pendidikan. saran berikutnya adalah UNP harus merumuskan permasalahan ketimpangan gender di masing - masing fakultas lalu mencari faktor penyebab terjadinya ketimpangan tersebut dan kemudian merumuskan solusi untuk mengatasi kesenjangan gender.

Riset yang ke-empat adalah riset yang dilakukan oleh Andriani \& Maisarah (2018) bahwa penelitian ini mengulas bagaimana mengartikulasikan kesetaraan gender dan bagaimana pilan perguruan tinggi memiliki responsifitas terhadap persoalan gender sebagai bentuk implementasi dalam merespon kesetaraan gender. Menariknya riset ini juga membuka pengetahuan kiyta akan ketimpangan menyoal gender di perguruan tinggi (Andriani \& Maisarah, 2018). Yang terakhir ke-lima adalah riset yang dilakukan oleh Harun (2019) meskipun riset ini tidak secara eksplisit menggambarkan kesetaraan gender di ranah pendidikan tinggi, namun riset ini mengulas hal yang menarik yaitu bagaimana perempuan mampu menjadi subjek politik dan membentuk paradigma nya sendiri sehingga memiliki pengaruh terhadap lingkungan dimana beliau berada. Dengan persfektif ini sebenarnya mencoba mengelaborasi dan mengartikulasikan ketimpangan terhadap gender melalui pembentukan paradigma baru melalui peningkatan kapasitas perempuan sebagai subjek politik.

Penelitian kali ini memiliki fokus dan berusaha untuk mengisi kekosongan antara kelima penelitian sebelumnya yaitu sebuah pandangan yang holistik untuk mewujudkan kampus responsif gender (Harun, 2019). Memahami kampus responsif gender tidak bisa lagi terkotakkan hanya melihat aspek kebijakan saja atau melihat aspek implementasi kebijakan, tetapi harus bisa merangkum secara keseluruhan mulai perumusan kebijakan, implementasi hingga evaluasi yang melibatkan perempuan Penelitian ini 
mencoba menawarkan pola pandang bagaimana mewujudkan kampus responsif gender termasuk menerjemahkan indikator yang sudah ditentukan oleh Kementerian PPPA terkait kampus responsif gender.

Penelitian ini dilakukan dengan menggunakan pendekatan fenomenologi. Fenomenologi sebagai sebuah pendekatan memberikan ruang yang besar dalam interpretasi data. Tidak hanya data yang nampak dalam kajian peneliti, namun juga data yang muncul dalam kesadaran peneliti (Creswell \& Creswell, 2018). Dalam melihat konsep kampus berperspektif gender yang mampu menampung dan memberikan kesempatan terhadap aksesibilitas perempuan, pendekatan fenomenologi mencoba mendefinisikan fenomena tersebut. Dalam pendekatan fenomenologi juga memungkinkan bagi peneliti dalam melihat makna di balik sebuah fenomena (PadillaDiaz, 2015).

Epoche dalam pendekatan fenomenologi memberikan ruang bagi peneliti dalam mengungkap data dari fenomena yang ada (Padilla-Diaz, 2015). Konsep Epoche dalam fenomenologi juga membuka berbagai kemungkinan bagi peneliti karna harus melihat berbagai macam data, varibel dan juga melakukan penundaan bagi asumsi-asumsi yang ada (Hikmawan, 2017). Konsep kampus berperspektif gender tidak hanya dimaknai sebagai kumpulan konsep, tetapi juga melihat lebih jauh terkait bagaimana konsep ini mampu menjamin kesetaraan dan kesempatan yang sama akses terhadap pendidikan.

Selanjutnya peneliti melakukan reduksi eidetik, dimana ada pemutkahiran analisis dengan mereduksi data yang ada jika data tersebut tidak berkorelasi atau memiliki korelasi negatif terhadap Analisa dan penelitian. Selanjutnya adalah tahapan eidos, dimana peneliti merumuskan Analisa yang komprehensif dari data yang nampak dan hasil reduksi data. Dengan demikian, penelitian ini menjadi penelitian yang komperhensif dalam menjelaskan permaslahan yang dihadapi. Lebih jauh penelitian ini juga diharapkan mampu menjelaskan apa yang akan terjadi ke depannya dengan segala kemungkinan yang ada (Hikmawan, 2017). Jadi baik secara teoritik maupun praktis pendekatan ini membantu peneliti dalam menjelaskan segala kemungkinan yang di hasilkan dari penelitian ini.

\section{Kebijakan Pengarustamaan Gender}

Pengarustamaan Gender merupakan amanat yang harus dijalankan oleh setiap kementerian/Lembaga baik di pemerintah pusat maupun pemerintah daerah sesuai dengan Instruksi Presiden No 9 Tahun 2000 tentang Pengarusutamaan Gender dalam Pembangunan. Sebagai sebuah strategi pembangunan, PUG dilaksanakan untuk menjamin kesetaraan dan keadilan gender dengan cara mengintegrasikan kepentingan, aspirasi dan kondisi laki - laki serta perempuan. Instruksi Presiden ini bertujuan untuk menurunkan kesenjangan antara laki - laki dan perempuan dalam memperoleh akses dan manfaat pembangunan (KemenPPPA, 2011). Keterlibatan perempuan didorong dalam tahapan pembangunan mulai dari perencanaan, pelaksanaan hingga pemantauan 
dan evaluasi. Keberhasilan pembangunan yang didasarkan pada pengarusutamaan gender tidak lagi dilihat secara kuantitas dengan membandingkan jumlah proporsi lakilaki maupun perempuan. Meskipun keterwakilan dari sisi jumlah penting untuk dilihat, tetapi ada persoalan yang jauh lebih substansial yaitu melihat apakah kepentingan perempuan terakomodasi di dalam pembangunan atau tidak.

Oleh karena itu, berbicara tentang pengarusutamaan gender maka akan berfokus pada dua pembahasan utama yaitu pertama menjamin kepentingan baik laki - laki maupun perempuan terintegrasi dalam proses pembangunan, terutama dalam proses pengambilan keputusan yang selama ini jarang melibatkan perempuan karena minimnya representasi perempuan di tingkat pimpinan pengambil keputusan. Kedua, memastikan bahwa baik laki - laki maupun perempuan secara bersamaan dapat memiliki akses dan menikmati hasil pembangunan. Hal ini selaras dengan mandat Sustainable Development Goals yaitu mencapai kesetaraan gender dan memberdayakan kelompok perempuan.

Untuk mewujudkan tujuan tersebut maka ada beberapa langkah yang disa dilakukan (United Nations, 2014). Langkah awal adalah memastikan bahwa setiap pembangunan harus bersifat keberlanjutan dan secara eksplisit menunjukkan komitmen atas kesetaraan dan pemberdayaan atas perempan. Selanjutnya adalah mensinergikan antara pembangunan yang keberlanjutan dengan kesetaraan gender termasuk mengidentifikasi tantangan yang akan dihadapi. Berikutnya, menegosiasikan tantangan yang dihadapi dengan mengutamakan prinsip inklusivitas serta peran aktif masyarakat sipil, organisasi perempuan dan komunitas yang memang concern pada isu kesetaraan.

Namun dalam pelaksanaannya, pengarustamaan gender dalam pembangunan ini masih menemui beberapa tantangan seperti pandangan bahwa gender merupakan persoalan individu yang lahir karena konstruksi dari budaya atau nilai tertentu sehingga sifatnya tidak akan mungkin dibawa pada kelembagaan formal. Hal ini tentu akan menghambat proses pengarustamaan gender. Tantangan berikutnya adalah isu gender masih dimaknai sebagai isu parsial yang penyelesaiannya tidak membutuhkan jejaring dan keterlibatan berbagai pihak. Justru pengarustamaan gender akan berhasil jika didukung oleh berbagai pemangku kepentingan. Dan tantangan berikutnya yang juga cukup penting adalah masih banyak ditemuinya regulasi baik di tingkat nasional maupun lokal yang justru tidak berpihak dan mengancam kesetaraan gender.

\section{Kampus Responsif Gender}

Salah satu upaya untuk mengimplementasi pengarusutamaan gender di bidang pendidikan, terutama pendidikan tinggi adalah dengan merancang dan menjalankan kampus resposif gender. Apalagi hal ini diamanatkan dalam UU No 12 Tahun 2012 tentang Pendidikan Tinggi pasal 6 yang menyebutkan bahwa perguruan tinggi haruslah diselenggarakan berlandaskan prinsip demokratis dan berkeadilan. Selain itu, perguruan 
tinggi haruslah menjunjung tinggi hak asasi manusia, nilai agama, budaya, kemajemukan, persatuan dan kesatuan bangsa. Hal ini tercermin melalui perilaku anti diskriminatif.

Kementerian Pemberdayaan Perempuan dan Perlindungan Anak dalam salah satu publikasinya menyebutkan bahwa pendidikan responsif gender adalah bagaimana pendidikan memastikan memberikan perlakukan dan kesempatan yang sama antara laki-laki dan perempuan untuk memperoleh pendidikan, salah satu cara yang bisa dilakukan adalah dengan memberikan materi perkenalan terkait gender sejak mereka menjadi mahasiswa baru (KemenPPPA, 2011). Atau cara lain yang bisa dilakukan adalah dengan menyusun kurikulum yang mengakomodasi kajian gender atau bahkan menyelipkan gender sebagai mata kuliah khusus.

Kampus Responsif Gender merupakan sebuah program yang diinisasi oleh Kementerian PPPA. Langkah awal untuk menjalankan program ini adalah pada tahun 2019 Kementerian PPPA bekerjajama dengan Pusat Studi Gender dan Perlindungan Anak Uhamka untuk merumuskan Panduan Perguruan Tinggi Responsif Gender. Kementerian PPPA juga menyelenggarakan workshop pada tahun 2019 yang mengundang akademisi dari berbagai perguruan tinggi dan Lembaga riset untuk merumuskan langkah - langkah pengarustamaan gender di perguruan tinggi. Sasaran pengarusutamaan gender adalah baik di bidang Tri Darma Perguruan Tinggi (pendidikan, penelitian dan pengabdian masyarakat) serta manajemen kampus. Pelibatan mahasiswa sebagai pihak yang juga aktif melakukan perubahan dianggap penting karena konsep responsif gender membutuhkan pola pandang holistik yang melibatkan seluruh civitas akademika kampus mulai dari pimpinan perguruan tinggi, tenaga pendidik, tenaga kependidikan, staf umum, hingga mahasiswa.

Program ini kemudian dilanjutkan dengan pilot project pada 9 Perguruan Tinggi Keagamaan Islam yang dianggap telah adil gender dalam bidang Tri Darma Perguruan Tingginya, yaitu UIN Syarif Hidayatullah, Universitas Muhamadiyah Prof. Dr Hamka, STAI Al-Hikmah Jakarta, Institut PTIQ Jakarta, UIN Sunan Ampel Surabaya, UIN Walisongo Semarang, UIN Sumatera Utara, UIN Jambi, dan IAIN Kendari (Republika, 2016). Saat ini secara nasional sudah terdapat 20 Universitas yang terdiri dari 11 Perguruan Tinggi Negeri dan 9 Perguruan Tinggi Swasta yang dianggap Kementerian PPPA masuk dalam Perguruan Tinggi Responsif gender karena sudah memiliki Profil Gender Perguruan Tinggi.

Kampus Responsif Gender merupakan sebuah pola pandang yang menjunjung tinggi prinsip inklusivitas. Inklusivitas sosial membuka ruang dan merangkul semua orang tanpa terkecuali melihat latar belakangnya untuk merasa aman dan nyaman (Fathy, 2019). Prinsip inklusivitas memposisikan kebutuhan setiap orang berbeda baik itu laki - laki, perempuan maupun penyandang disabilitas. Penyandang disabilitas dianggap sebagai bagian dari kampus responsif gender, sehingga menjadi pekerjaan 
rumah bagaimana perguruan tinggi untuk menciptakan kampus yang ramah bagi perempuan maupun disabilitas. Dengan pengarusutamaan gender, maka kebutuhan masing - masing pihak ini akan diakomodasi sehingga dapat tercapai Perguruan Tinggi Responsif Gender. Perguruan Tinggi Responsif Gender merupakan kampus yang dalam kegiatannya, kebijakan maupun proses penganggarannya memperhatikan keberbedaan pengalaman, kebutuhan dan aspirasi dari seluruh civitas akademika, yang tercermin melalui penetapan, pelaksanaan, evaluasi, pengendalian dan peningkatan tata kelola serta Tridharma Perguruan Tinggi melalui strategi Pengarusutamaan Gender (KemenPPPA, 2011).

Kampus Responsif Gender urgen untuk diterapkan pada setiap perguruan tinggi yang ada di Indonesia karena adanya kompleksitas keberbedaan kebutuhan masing masing pihak. Kekhususan kebutuhan pada perempuan dan penyandang disabilitas tidak akan bisa teridentifikasi jika pemangku kepentingan tidak responsif gender. Apalagi jika kebijakan yang dikeluarkan sifatnya netral gender (memposisikan kebutuhan perempuan, laki - laki dan penyandang disabilitas sama), maka sudah tentu perempuan dan penyandang disabilitas akan menjadi pihak yang dirugikan dalam proses pendidikan. Agar semua pihak mampu mendapatkan manfaat yang sama dan kualitas kehidupannya meningkat maka pemimpin harus memastikan setiap civitas akademika dapat mengakses serta berperan aktif dalam proses pembangunan di kampus. Perguruan Tinggi Responsif Gender memiliki tujuan dalam menyamakan hak-hak yang diperoleh sivitas akademik, baik oleh perempuan dan laki-laki dalam bidang pendidikan, pengabdian hingga penelitian yang merupakan tridharma perguruan tinggi. Kesetaraan gender menjadi harapan yang nantinya bisa dicapai dalam kampus repsonsif gender, agar kegiatan-kegiatan dalam tridharma perguruan tinggi bisa dilakukan dengan khususnya memperhatikan kebutuhan kaum perempuan dan kaum disabilitas.

\section{Upaya Mendorong Untirta Banten sebagai Kampus Responsif Gender}

Kampus responsif gender menjadi salah satu tujuan yang harus dilakukan oleh semua perguruan tinggi, termasuk perguruan tinggi di Indonesia. Kampus responsif gender dapat diwujudkan ketika semua pemangku kepentingan bersama-sama memiliki konsen terhadap perempuan dan memasukan kepentingan perempuan ketika membuat kebijakan maupun sarana-prasarana serta fasilitas yang memperhatikan kepentingan mereka. Hal ini senyatanya bukan bermaksud menspesialkan mereka, namun agar kebutuhan perempuan menjadi terakomodasi dengan baik mengingat bahwa perempuan memiliki peran ganda yang membuat kebutuhan antara laki-laki dan perempuan cukup berbeda.

Di Indonesia, sudah adabeberapa perguruan tinggi yang sedang berproses atau menuju kampus responsif gender. Salah satu perguruan tinggi yang sedang mengembangan kampus responsif gender ialah UIN Walisongo Semarang, dimana 
Rektor UIN Walisongo Semarang Prof Dr H Imam Taufiq MAg menegaskan tentang pentingnya perguruan tinggi responsif gender. Dalam pernyataanya, beliau menegaskan "Pengarustamaan gender semestinya menjadi paradigma, semangat dan perilaku dalam pengelolaan kampus, baik manajemen kelembagaan maupun pengembangan universitas" (UIN Walisongo, 2017). Lebih lanjut, menurut beliau bahwa program dan kebijakan UIN Walisongo selalu mempertimbangkan aspek gender. Tidak hanya layanan berkeadilan antara laki-laki dan perempuan, namun juga pemenuhan dasar sarana prasarana berwawasan gender, misalnya tempat laktasi, tempat penitipan anak dan lain sebagainya.

UMSU juga menjadi salah satu perguruan tinggi yang sudah menuju kampus responsif gender di Indonesia. Dalam Perguruan Tinggi Responsif Gender (PTGR), terdapat Sembilan indikator yang harus di raih sebuah perguruan tinggi menuju PTGR. Sembilan indikator PTGR, yaitu adanya PSGA, Profil Gender Perguruan Tinggi, Peraturan Rektor tentang Implementasi PUG di Perguruan Tinggi, Standar Mutu Pendidikan yang Responsif Gender, Standar Mutu Pengabdian Masyarakat yang Responsif Gender, Tata Kelola Perguruan Tinggi yang Responsif Gender, Peran Serta Civitas Akademika dalam Perencanaan - Evaluasi dan Tindak Lanjut Tri Dharma Perguruan Tinggi yang Responsif Gender, dan Zero Tolerance kekerasan terhadap perempuan dan Laki-laki. Lebih lanjut, Sahran Saputra selaku Sekretaris PSGA UMSU memaparkan bahwa dari sembilan indikator tersebut, beberapa sudah dilakukan, dan sisanya sudah masuk dalam roadmap yang tertuan dalam Rencana Kerja Tahunan (RKT) PSGA UMSU (Universitas Muhamadiyah Sumatera Utara, 2020).

Dari paparan tersebut, dapat dlihat bahwa beberapa perguruan tinggi di Indonesia sudah dalam proses menuju perguruan tinggi responsif gender (PTGR). PTGR yang menjadi langkah dalam penyeimbangan kepentingan, baik bagi laki-laki dan perempuan menjadi penting untuk dilakukan oleh semua perguruan tinggi tanpa kecuali. Termasuk salah satunya ialah Universitas Sultan Ageng Tirtayasa yang merupakan peguruan tinggi negeri di Provinsi Banten, Indonesia. Universitas Sultan Ageng Tirtayasa atau disingkat Untirta merupakan Perguruan Tinggi Negeri (PTN) di Provinsi Banten, dengan kampus utama di Serang, kampus Fakultas Teknik yang berada di Cilegon, dan Fakultas Keguruan yang berada di Ciwaru. Selain itu, kampus Untirta juga memiliki kampus baru yang baru diselesaikan di tahun 2020 yang berada di Sindangsari.

Visi misi Untirta tahun 2019-2023 yakni terwujudnya Untirta sebagai "Integrated Smart and Green (It's Green) University yang Unggul, Berkarakter dan erdaya Saing di Kawasan ASEAN 2030. Sedangkan misi Untirta meliputi: a). Meningkatkan kualitas, relevansi dan daya saing pendidikan serta lulusan yang unggul, berkarakter dan berdaya saing di kawasan ASEAN; b) Meningkatkan kualitas dan kuantitas penelitian dan pengabdian kepada masyarakat yang inovatif berbasis kebutuhan nyata sesuai perkembangan zaman; dan c). Meningkatkan daya dukung tatakelola perguruan tinggi yang baik sebagai implementasi dari Integrated Smart and Green (It'S Green) University. 
Dengan visi dan misi demikian membuat Untirta menjadi salah satu kampus yang memiliki potensi unggul dalam ranah perguruan tinggi di Indonesia. Oleh sebab itu, penerapan kampus reponsif gender juga senyatanya sangat perlu dilakukan bagi Untirta. Meskipun saat ini terjadi ketidakmerataan perempuan dan laki-laki dalam jabatan pimpinan di Untirta, dimana dari 22 jabatan pimpinan seperti Rektor, Wakil Rektor, Dekan dan Kepala Lembaga hanya ada 1 pimpinan perempuan sebagai Dekan (4\%). Namun hal tersebut seharusnya tidak menghalangi terciptanya kebijakan yang ramah perempuan. Selain ketidakmerataan dalam jabatan pimpinan, jumlah dosen tetap perempuan di lingkungan Untirta juga masih jauh jumlahnya jika dibandingkan dengan dosen tetap laki-laki, dimana dosen perempuan Untirta berjumlah 348 orang sedangkan dosen tetap laki-laki berjumlah 457 orang (PDDIKTI Kemdikbud, 2020). Hal yang sama juga terjadi pada dosen tidak tetap, dimana jumlah dosen tidak tetap laki-laki berjumlah 13 orang dan dosen tidak perempuan berjumlah 12 orang.

Dengan data diatas dapat dilihat bahwa representasi perempuan, baik di tingkat pimpinan maupun pengajar di lingkungan Untirta masih kurang bila dibandingkan dengan laki-laki. Kurangnya representasi ini dapat menimbulkan kecenderungan adanya bias kebijakan bagi perempuan apabila pemangku kepentingan laki-laki tidak memperhatikan atau tidak memiliki konsen terhadap perempuan. Sarana prasarana serta fasilitas di kampus Untirta juga saat ini masih belum ramah perempuan, dimana saat ini belum tersedianya ruang laktasi bagi dosen atau tenaga pendidik perempuan yang menyusui, tempat penitipan anak, ruang toilet dosen perempuan yang masih belum ada pemisahan dengan toilet laki-laki, dan tangga ramah perempuan. Belum tersedianya fasilitas-fasilitas ramah perempuan ini tentunya dapat menghambat kinerja dosen maupun tenaga pendidik perempuan, karena perempuan memiliki peran ganda maka dengan adanya sarana prasarana serta fasilitas yang ramah perempuan dapat menunjang kinerja atau memudahkan perempuan dalam menjalankan aktiftasnya dilingkungan kerja.

Pemerintah melalui PP nomor 33 Tahun 2012 tentang Pemberian ASI Eksklusif telah mengamanatkan seluruh komponen publik agar bersinergi untuk mendukung ibu menyusui bayi dan memompa ASI nya dengan menyediakan ruang laktasi yang layak di ruang publik. Oleh sebab itu, pengadaan ruang laktasi bagi ibu menyusui khususnya bagi perguruan tinggi dimana dosen atau tenaga pengajar perempuan umumnya merupakan perempuan yang sudah menikah dan berkeluarga (memilki bayi) sangat diperlukan demi menunjang kinerja mereka selama bekerja. Meskipun terlihat seperti masalah yang sederhana, namun kebutuhan ruang bagi ibu yang bekerja senyatanya merupakan hal yang penting bagi ibu dan juga bayi. Ibu membutuhkan supporting system yang memadai pasca cuti melahirkan, maka saat kembali bekerja sang ibu akan memerlukan upaya agar bisa menyusui ASI eksklusif bagi bayinya namun tetap bisa menunaikan pekerjaanya. Oleh sebab itu, selain dukungan dari keluarga baik suami dan anak, dukungan dari lingkungan kerja juga sangat dibutuhkan perempuan. 
Hal ini juga sama bagi tersedianya ruangan toilet yang terpisah, khususnya bagi dosen dan tenaga pendidik di lingkungan Untirta. Perempuan dan penyandang disabilitas memiliki kebutuhan atau kekhususan masing-masing sehingga penting bagi mereka harus disediakan toilet yang terpisah, selain demi kebersihan juga demi kenyamanan baik laki-laki dan perempuan. Tangga ramah perempuan dan penyandang diasbilitas pun juga sama, dimana hadirnya tangga yang ramah bagi perempuan di lingkungan Untirta sangat dibutuhkan mengingat bahwa dosen dan tenaga pendidik perempuan di Untirta tidak sedikit. Oleh sebab itu, penting bagi Untirta untuk menyediakan fasilitas yang ramah perempuan. Fasilitas yang ramah perempuan juga tidak hanya dibutuhkan oleh dosen dan tenaga pendidik Untirta, namun tentu saja oleh mahasiswi Untirta. Dengan fasilitas serta kebijakan yang ramah perempuan dapat menjadikan Untirta menjadi perguruan tinggi yang responsif gender.

Terwujudnya kampus Untirta menjadi kampus responsif gender tentunya akan mewujudkan kampus yang lebih ramah perempuan, sehingga tindak-tindak yang membahayakan perempuan seperti pelecehan seksual dan tindakan yang menganggu kenyamanan perempuan akan berkurang atah bahkan hilang. Selain itu, kampus responsif gender juga akan menjadi rumah yang nyaman, tidak hanya bagi dosen dan tenaga pendidik namun juga mahasiswi di lingkungan Untirta. Rumah yang nyaman sangat diperlukan perempuan sehingga mereka bisa belajar dan bekerja dengan lebih nyaman, serta bisa menjadi tempat berlindung bagi perempuan. Seperti yang sudah dijelaskan sebelumnya bahwa penerapan kampus repsonsif gender juga diperlukan karena adanya kompleksitas keberbedaan kebutuhan masing - masing pihak. Tidak hanya bagi perempuan, namun juga bagi penyandang diasbilitas terlebih disabilitas perempuan. Maka fasilitas yang di barengi dengan kebijakan dari kampus harus dilakukan. Hal tersebut akan lebih mudah terwujud saat para pemangku kebijakan kampus ialah para pemimpin yang responsif gender.

Selain visi misi, Untirta juga memiliki moto nilai khusus yang dijunjungnya yakni "Jawara" dimana Jawara merupakan singkatan dari Jujur, Adil, Wibawa, Amanah, Religius dan Akuntabel. Selain itu, Untirta juga merupakan rumah yang tidak hanya berperan sebagai tempat, namun juga sebagai sumber pengetahuan, keteladanan, dan kebajikan. Oleh karena itu seluruh sivitas akademikanya berkewajiban menjunjung tinggi nilai-nilai dasar dalam melaksanakan tugas dan tanggungjawabnya." Dari pernyataan tersebut dapat dilihat bahwa Untirta memiliki tujuan mulia sebagai sebuah perguruan tinggi negeri, oleh karena itu peningkatan kualitas pengajar yang dibarengi dengan dengan peningkatan fasilitas bagi pengajar dan juga mahasiswi perlu dilakukan, khsususnya bagi perempuan yang selama ini selalu mendapat tempat kedua bila dibandingkan dengan laki-laki.

Hadirnya kampus baru Untirta yakni kampus Sindangsari akan membawa banyak perubahan mengingat beberapa fakultas di kampus Untirta pakupatan akan dipindahkan ke Sindangsari, seperti Fakultas Ekonomi, Fakultas Hukum, Fakultas 
Pertanian dan Fakultas IImu Sosial dan Ilmu Politik. Kampus Sindangsari menjadi salah satu peningkatan dan pengembangan Untirta menuju Integrated Smart and Green (It'S Green) University, namun sayangnya hadirnya kampus baru Untirta Sindangsari masih belum dibarengi dengan adanya pembaruan sarana prasaran serta fasilitas yang ramah perempuan.

Rektor Untirta, Fatah Sulaiman juga bertekad membawa Untirta menjadi kampus yang naik level ke ASEAN dengan konsep kampus yakni "integrated, smart and green university dan menargetkan Untirta sebagai kampus rujukan di level kawasan Asia Tenggara (Bantenprov, 2019). Selanjutnya, Fatah Sulaiman mencanangkan bahwa pada 2020 infrastruktur-infrastruktur yang terintegrasi, cerdas, dan hijau rampung dibangun. Area lahan sekitar 12 hektar di Untirta Sindangsari akan dibangun 11 gedung. Kesebelas gedung itu diantaranya gedung rektorat, kuliah terpadu, perpustakaan, auditorium, laboratorium terpadu, Fakultas Hukum, Fakultas FISIP, Fakultas Fakultas Ekonomi Bisnis, Fakultas Pertanian, asrama putra, asrama putri dan pintu gerbang. Dengan cita-cita besar demikian, sangat disayangkan bahwa kampus Sindangsari Untirta masih belum memiliki sarana prasrana dan fasilitas yang mendukung kesetaraan gender. Ruang laktasi, dan tempat penitipan anak menjadi fasilitas yang ternyata masih belum tersedia di Kampus Sindangsari Untirta. Hal ini cukup disayangkan mengingat Untirta memiliki visi misi yang potensial sebagai perguruan tinggi di Indonesia.Terlebih mengingat bahwa Unirta memiliki jumlah pengajar dan tenaga pendidik perempuan yang tidak sedikit jumlahnya.

Dalam mendorong Untirta sebagai kampus responsif gender di Indonesia, maka peran akademisi dan lembaga riset di Untirta dalam pengharusutamaan gender sangat diperlukan agar seluruh sivitas Untirta dapat melahirkan kampus yang responsif gender. Dari segi peraturan di tingkat Perguruan Tinggi, Undang-Undang No 12 Tahun 2012 tentang Pendidikan Tinggi pasal 6 poin (b) berbunyi bahwa Pendidikan Tinggi diselenggarakan dengan prinsip demokratis dan berkeadilan serta tidak diskriminatif dengan menjunjung tinggi hak asasi manusia, nilai agama, nilai budaya, kemajemukan, persatuan, dan kesatuan bangsa (dikutip dalam kemenpppa.go.id). Oleh sebab itu, penting bagi lembaga pendidikan, termasuk perguruan tinggi seperti Untirta untuk bisa memasukan kebijakan yang ramah dan tidak diskriminatif terhadap perempuan agar keseteraan gender dapat terwujud. Apabila keseteraan gender dapat diwujudkan di Untirta, maka kesempatan perempuan sebagai pembuat keputusan dan menempati posisi strategis di kampus akan semakin meningkat. Tidak hanya itu, kebijakan dan sarana prasarana serta fasilitas yang ramah perempuan juga bias terwujud. Dan lebih penting lagi, tindak kekerasan terhadap perempuan serta tindak pelecehan seksual yang sering menimpa perempuan juga akan terminimalisir atau bahkan terhapus secara tuntas di lingkungan kampus. 


\section{Penutup}

Perguruan Tinggi memiliki peran yang cukup stategis untuk mendorong transformasi sosial terkait kesetaraan gender melalui program kampus responsif gender. Pola pendidikan yang netral gender tanpa sadar melanggengkan praktik diskriminasi berbasis gender. Perlu ada upaya nyata dari perguruan tinggi untuk mewujudkan transformasi dimulai dengan mewujudkan indikator kampus responsif gender.

Kesetaraan gender menjadi suatu hal yang harus segera dilakukan oleh semua perguran tinggi di Indonesia tanpa terkecuali. Hal ini karena kebutuhan perempuan berbeda dengan laki-laki, maka kebijakan dan penyediaan sarana prsarana serta fasilitas pendukung bagi perempuan akan sangat membantu tidak hanya dalam keseharian mereka selama bekerja namun juga bisa menunjang kinerja mereka dilingkungan kerjanya. Kebijakan dan sarana prasaran serta fasilitas yang reponsif gender juga akan mengurangi tindak-tindak kekerasaran terhadap perempuan dan pelecehan terhadap perempuan di lingkungan kampus. Hal ini juga bisa mendukung terciptanya rumah yang nyaman bagi perempuan di lingkungan kampus, baik bagi pengajar dan tenaga pendidikan namun juga mahasiswi perempuan.

Untirta sebagai perguruan tinggi di Provinsi Banten sayangnya belum memiliki sarana prasarana serta fasilitas yang responsif gender, termasuk kampus baru Untirta di Sindangsari. Perwujudan kampus responsif gender harus disegerakan di Untirta agar nantinya cita-cita besar Untirta untuk bisa menjadi role model perguruan tinggi di kawasan Asia Tenggara dapat terwujud dengan baik. Hal ini mengingat bahwa permasalahan kesetaraan gender bukanlah permasalahan yang ada di Indonesia, namun juga diseluruh dunia, maka terciptanya Untirta sebagai perguruan tinggi yang responsif gender dapat meningkatkan Untirta dimata dunia.

\section{Ucapan Terima Kasih}

Terimakasih sampaikan kepada semua kolega yang telah mengkritisi dan membuat riset ini menjadi lebih kaya akan perspektif.

\section{Pendanaan}

Penulisan artikel ini dilakukan atas pembiayaan dari dana DIPA FISIP Universitas Sultan Ageng Tirtayasa

\section{Daftar Pustaka}

Alfirahmi. (2018). Kontruksi Realitas Sosial Perempuan Tentang Gender Dalam Pembentukan Karakteristik Anak Terhadap Pemahaman Gender. Mediakom Jurnal Ilmu Komunikasi, 2(2). https://doi.org/http://dx.doi.org/10.35760/mkm.2018.v2i2

Andriani, E., \& Maisarah, M. M. (2018). Wanita dan Pendidikan : Elaborasi Makna Kesetaraan Gender di Perguruan Tinggi. Al Huda, 10, 53-72. 
Aruan, C. D. (2019). Sumber Daya Manusia dan Produktivitas. Jakarta.

Bantenprov. (2019). Kampus Terpadu Sindangsari Selesai 2020, Untirta Bertekad Bersaing di ASEAN.

Button, B. (2016). Sexually harassed and abused on campus.

Cerise, S., \& Francavilla, F. (2012). Tackling the root causes of gender inequalities in the post-2015 development agenda. Paris.

Creswell, J. W., \& Creswell, J. D. (2018). Qualitative, Quantitative, and Mixed Methods Approaches (fifth). United State of America: SAGE Publications.

Dikti, M. (2018). Indonesia Higher Education Statistical Year Book 2018. Chemistry - A European Journal. Jakarta: Ristekdikti. https://doi.org/10.1002/chem.200802548

Faizal, A. (2020). Kasus Fetish Kain Jarik, Pelaku Dikeluarkan dari Kampus, Orangtua Pasrah.

Fakih, M. (1996). Analisis Gender dan Transformasi Sosial, Yogyakarta. Insist Press.

Farmawati, C. (2018). Peningkatan Peran Masyarakat dalam Pencegahan KDRT Melalui Penyuluhan Anti Kekerasan Berbasis Gender, 10(2), 138-161. https://doi.org/https://doi.org/10.28918/muwazah.v10i2.1779

Fathy, R. (2019). Modal Sosial: Konsep, Inklusivitas dan Pemberdayaan Masyarakat. Jurnal Pemikiran Sosiologi, 6(1), 1. https://doi.org/10.22146/jps.v6i1.47463

Hannam, J. (2012). Feminism. England: Pearson Education Limited.

Harun, N. I. (2019). New Paradigm For Strengthening Women's Political Capacity in the Process of Public Policy Processing. Journal of Governance, 4(2), 171-186. https://doi.org/10.31506/jog.v4i2.6526

Hikmawan, M. D. (2017a). Pluralisme Demokrasi Politik di Indonesia. Journal of Governance, 2(2),

223-247. https://doi.org/http://dx.doi.org/10.31506/jog.v2i2.2678

Hikmawan, M. D. (2017b). Politik Perbedaan: Minnoritas dalam Implementasi Kebijakan. Journal of Indonesian Public Administration and Governance Studies (JIPAGS), 1(1), 88-98.

Indrarini, I. (2020). Gender dalam Infrastruktur. Jakarta.

Jabar, M., Djamas, D., \& Latisma, D. (2012). Analisis Kebijakan Pendidikan Berwawasan Gender Di Universitas Negeri Padang. Humanus, XI(2), 97-102.

Jurnal Perempuan. (2016). Status Perempuan dalam STEM (Sains, Teknologi, Engineerin, Matematika), 21(4).

KemenPPPA. (2011). Kertas Kebijakan Pengarustamaan Gender. Jakarta.

Kurniawan, D. (2020). Unair Beri Konseling kepada Korban Terkait Kasus "Fetish Kain" Berkedok Riset.

Kusmanto, T. Y. (2017). Dinamika Pengarusutamaan Gender Pada Pendidikan Tinggi Islam. Jurnal SAWWA, 12(3), 303-320.

Maudy, C. (2018). Nalar Pincang UGM atas Kasus Perkosaan.

Padilla-Diaz, M. (2015). Phenomenology in Educational Qualitative Research: 
Philosophy as Science or Philosophical Science? International Journal of Educational Excellence (2015), 1(2), 101-110.

PDDIKTI Kemdikbud. (2020). Statistik PDDikti.

Republika. (2016). Perkuliahan Responsif Gender.

Roziqin, A., Suwitri, S., Apryanto, A. A., \& Sihidi, I. T. (2019). Pendidikan Berbasis Kesetaraan Gender Di Provinsi Jawa Tengah. Jurnal IImu Sosial Socia, 16(2), 202210. https://doi.org/10.21831/socia.v16i2.30213

UIN Walisongo. (2017). Kuatkan Pengarusutamaan Gender, UIN Walisongo Teken MoU dengan KPP-PA.

United Nations. (2014). Gender Equality and Sexuality Developments. United State: United Nations Publication.

Universitas Muhamadiyah Sumatera Utara. (2020). UMSU Satu-satunya PT Responsif Gender.

\section{Tentang Penulis}

Ika Arinia Indriyany adalah seorang Dosen di Ilmu Pemerintahan FISIP Universitas Sultan Ageng Tirtayasa. Penulis memiliki fokus riset seputar gender, feminisme dan gerakan sosial.

M. Dian Hikmawan adalah seorang Dosen di Ilmu Pemerintahan FISIP Universitas Sultan Ageng Tirtayasa. Penulis memiliki fokus riset seputar HAM dan Demokrasi, Citizenship, masyarakat sipil dan juga gerakan sosial.

Wahyu Kartiko Utami adalah seorang Dosen di Ilmu Pemerintahan FISIP Universitas Sultan Ageng Tirtayasa. Penulis memiliki fokus riset seputar politik lingkungan, kebijakan publik dan ketahanan pangan. 